\title{
Aqueous chemistry of anthropogenically contaminated Bengaluru lakes
}

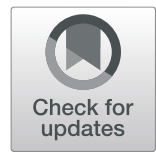

Sudhakar Rao ${ }^{1 *}$, Nitish V. Mogili², Priscilla $A^{1}$ and Lydia $A^{1}$

\begin{abstract}
Anthropogenic activities impact the major ion composition of fresh water sources. The inorganic species are likely to be influenced by mineral dissolution, mineral precipitation, redox and ion-exchange reactions in the contaminated lakes. Owing to paucity of research, this study examines the influence of bio-geochemical reactions on the major ion composition of sewage contaminated Bengaluru lakes. The selected lakes represent water bodies in the major valley systems of the city that are polluted by partly treated sewage and stormwater runoffs. Hydrogeochemical facies of the lake samples showed that enrichment of $\mathrm{Mg}^{2+}, \mathrm{Na}^{+}, \mathrm{Cl}^{-}$and $\mathrm{SO}_{4}{ }^{2-}$ ions from anthropogenic contamination altered the chemical type of the lake-water. Examination of processes influencing the major ion composition of surface waters indicated that evaporation than rock-weathering tends to influence the chemical composition of the Bengaluru lakes. Precipitation of carbonate minerals in the alkaline $\mathrm{pH}$ contributed to the deficiency of alkaline earth ions, while dissolution of anthropogenic gypsum enhanced the $\mathrm{SO}_{4}{ }^{2-}$ ion concentration of the lakes. Solute diffusion from lake water into the pore solutions of sediments and ion-exchange reactions between monovalent ions of sediments and divalent cations in lake water are additional pathways that influence the major ion composition of the contaminated lakes. Besides alterations in major ion composition, organic contamination, biochemical reactions associated with photosynthesis activity of algae and release of toxic $\mathrm{Al}^{3+}$ ions from mineral dissolution are consequences of the lake contamination.
\end{abstract}

Keywords: Anthropogenic, Lakes, Geochemistry, Pollution, Wastewater

\section{Introduction}

The natural factors of lithology, weathering of drainage catchments, precipitation, climate and distance to marine environment influence the major ion composition of freshwater resources [1-4]. The geochemical processes of dissolution/precipitation, ion-exchange, evaporation/ crystallization and redox transformations control the fate of the inorganic species in the fresh water sources [4-8].

Anthropogenic contamination also impacts the major ion composition of freshwater resources. Contamination by fertilizers, animal waste, municipal and industrial sewage have altered the major ion composition $\left(\mathrm{SO}_{4}{ }^{2-}\right.$, $\mathrm{NO}_{3}{ }^{-}, \mathrm{Cl}^{-}$, and $\mathrm{K}^{+}$) of the river waters in Guizhou Province, China [7]. Use of manure and chemical fertilizers

\footnotetext{
* Correspondence: msrao@iisc.ac.in

${ }^{1}$ Department of Civil Engineering, Indian Institute of Science, Bengaluru 560012, India

Full list of author information is available at the end of the article
}

have contaminated the surface reservoirs of northwest Iran with $\mathrm{NO}_{3}^{-}, \mathrm{Cl}^{-}, \mathrm{HCO}_{3}^{-}$and $\mathrm{Na}^{+}$ions [8]. Anthropogenic activities related to agriculture have led to strong correlations between TDS (total dissolved solids) and major ion ratios $[7,9]$. Agricultural fertilizers caused significant increase in $\mathrm{Na}^{+}, \mathrm{SO}_{4}{ }^{2-}, \mathrm{K}^{+}, \mathrm{Cl}^{-}, \mathrm{NO}_{3}{ }^{-}$, and $\mathrm{Mg}^{2+}$ ion concentrations and altered the chemical ratios in the Seine river basin, France [2]. Nitrate pollution from agriculture and floating gardens led to a reverse correlation between nitrate and other major ions in the Dal lake samples of Gagribal and Nagin basins, India [10]. Dissolution of anthropogenic gypsum arising from idols immersed in urban lakes contributed to the $\mathrm{Ca}^{2+}$ ion concentrations of such water bodies [11].

Black water is rich in major cations and anions [12-15]; sewage contamination would thus alter the major ion composition of the contaminated lakes and rivers. Base flow solute concentrations $\left(\mathrm{SO}_{4}{ }^{2}, \mathrm{Cl}^{-}\right.$, 
$\mathrm{HCO}_{3}{ }^{-}$, and $\mathrm{Na}^{+}$) were observed to increase with the degree of urbanization in the Atlanta Metropolitan Region, USA, suggesting that septic tank systems and leaky sewer line functioned as pervasive low-level non-point sources of contamination affecting the chemistry of shallow groundwater. A strong and unusual basin-wide correlation between $\mathrm{Na}-\mathrm{K}-\mathrm{Cl}$ within the river basin reflected the widespread input of electrolytes present in human wastes and wastewater [16]. The composition of Bagmati river water in Kathmandu, Nepal, suggested that sewage effluent entering the river had a major effect on its major ion composition. All the chemical parameters showed strong correlations with population density suggesting that population density is the most likely driver of chemical load in drainage waters of the river [17]. Also, the microbial degradation of organic $\mathrm{C}$ and oxidation of $\mathrm{NH}_{4}{ }^{+}$ions $[12,18,19]$ will contribute to $\mathrm{HCO}_{3}{ }^{-}$and $\mathrm{NO}_{3}{ }^{-}$concentrations of sewage contaminated lakes and rivers. Occurrence of alkaline $\mathrm{pH}$ from photosynthetic metabolism of algae [20-23] can induce carbonate mineral precipitation $[24,25]$ and impact the alkaline earth $\left(\mathrm{Ca}^{2+}, \mathrm{Mg}^{2+}\right)$ and $\mathrm{HCO}_{3}{ }^{-}$ ion composition of sewage contaminated water bodies.

Earlier studies have highlighted the influence of anthropogenic contamination on the major ion composition of freshwater resources. Subsequent to their deposition, the inorganic species will possibly be influenced by dissolution/precipitation, ion-exchange, evaporation/crystallization and redox transformations in an environment affected by microbial and algal activities. The influence of bio-geochemical reactions on the major ion composition of contaminated freshwater resources has not been studied. The present study hence examines the influence of bio-geochemical reactions on the major ion composition of sewage contaminated Bengaluru lakes. The selected lakes represent water bodies in the major valley systems of Bengaluru city that are contaminated by partly treated sewage and stormwater runoffs.

\section{Study area}

Bengaluru is located in southeastern part of Karnataka extending from north latitude $12^{\circ} 39^{\prime} 32^{\prime \prime}$ to $13^{\circ} 14^{\prime} 13^{\prime \prime}$ and East longitude $77^{\circ} 19^{\prime} 44^{\prime \prime}$ to $77^{\circ} 50^{\prime} 13^{\prime \prime}$ at an altitude of $920 \mathrm{~m}$ above mean sea level. Most of Bengaluru lakes are irrigation tanks built in sixteenth century and are hydrologically connected to form a chain of lakes in a given valley system. Rapid urbanization of the city from 1980s has diminished the number of lakes; further insufficient recharge, inflow of partially treated sewage, stormwater runoffs and effluents have contaminated the existing lakes [26-28].
The lake beds are composed of residually derived red sandy soil that are overlaid by silt deposits of varying thickness $[29,30]$. The silt fraction of red soils deposited in lakes from rainwater runoffs are expected to be composed of kaolinite and silica minerals [29]. The area is mainly drained by part of Arkavathi river catchment to the west and south Pennar river to the east. The two main catchments are further sub-divided into three major valley watersheds namely the Hebbal Valley, Vrushabhavathi Valley, and Koramangala and Challaghatta (KC) Valley. Each of these valleys are endowed with two lake series, and each lake series in turn comprise of many lakes. The flow of water in each lake series is along a network of drains which facilitates surplus water from the lakes to flow into the downstream lake. Drain is a naturally or man-made channel which connects the lentic water bodies for the purpose of conveying the surplus water on land, particularly rainfall runoff. In Bengaluru City, most of the nonrejuvenated drains however carry sewage to water bodies and are chocked by siltation and weeds. The catchment areas of Hebbal valley, Vrushabhavathi valley and $\mathrm{KC}$ valley correspond to 207, 165, and $255 \mathrm{~km}^{2}$ respectively [31].

Among the lakes examined in this study, Puttenahalli lake (PU; KC valley) is the end member of the Puttenahalli lake series that does not drain further. Ulsoor lake (UL; KC Valley) is part of the Varthur lake series and the end-member of this series (Varthur lake) drains into the South Pinakini river. Sankey lake (SK; Vrushabhavathi Valley) is standalone lake and is fed by rainwater runoffs and stormwater drains. Nagawara lake (NG; Hebbal Valley) is part of the Yellamallappa Chetty lake series; the end member (Kacharakanahalli lake) of this lake series does not drain further.

The areal extent, elevation and coordinates (coordinates are obtained using Google Earth Pro software) of the lakes are presented in Table 1. The location of the four lakes and primary storm-water drains in the major valley systems of Bengaluru city are illustrated in Fig. 1. The maximum and average depths of PU, UL and NG lakes were measured in April-May 2019. The depth of each lake was measured at multiple points ( 4 to 9 ) with chain and solid metal ball $(4 \mathrm{~kg})$ assembly in consultation with local experts having knowledge of the lake topography. The maximum depths of PU, UL and NG lakes correspond to $2.1,3.3$, and $2.0 \mathrm{~m}$ respectively, while, their average depths are $1.43,2.5$ and $1.41 \mathrm{~m}$ respectively. The maximum and average depth of SK lake corresponds to $9.0 \mathrm{~m} \mathrm{[33]} \mathrm{and} 2.7 \mathrm{~m}$ [32] respectively. 
Table 1 Areal extent, elevation and coordinates of the lakes

\begin{tabular}{|c|c|c|c|}
\hline Name of the lake & Areal extent $(\mathrm{ha})^{\mathrm{a}}$ & Elevation $(m)^{a}$ & Location $^{\mathrm{b}}$ \\
\hline Sankey lake & 14.99 & 917 & $\begin{array}{l}\text { Lies between latitudinal parallels of } 13^{\circ} 0^{\prime} 27^{\prime \prime} \mathrm{N} \text { and } 13^{\circ} 0^{\prime} 44^{\prime \prime} \mathrm{N} \\
\text { and longitudinal meridians of } 77^{\circ} 34^{\prime} 22^{\prime \prime} \mathrm{E} \text { and } 77^{\circ} 34^{\prime} 37^{\prime \prime} \mathrm{E}\end{array}$ \\
\hline Nagawara lake & 23.49 & 896 & $\begin{array}{l}\text { Lies between latitudinal parallels of } 13^{\circ} 2^{\prime} 47^{\prime \prime} \mathrm{N} \text { and } 13^{\circ} 2^{\prime} 35^{\prime \prime} \mathrm{N} \\
\text { and longitudinal meridians of } 77^{\circ} 36^{\prime} 57^{\prime \prime} \mathrm{E} \text { and } 77^{\circ} 36^{\prime} 43^{\prime \prime} \mathrm{E}\end{array}$ \\
\hline Puttenahalli lake & 5.37 & 915 & $\begin{array}{l}\text { Lies between latitudinal parallels of } 12^{\circ} 53^{\prime} 29^{\prime \prime} \mathrm{N} \text { and } 12^{\circ} 53^{\prime} 21^{\prime \prime} \mathrm{N} \\
\text { and longitudinal meridians of } \\
77^{\circ} 35^{\prime} 9^{\prime \prime} \mathrm{E} \text { and } 77^{\circ} 35^{\prime} 17^{\prime \prime} \mathrm{E}\end{array}$ \\
\hline Ulsoor Lake & 40.59 & 905 & $\begin{array}{l}\text { Lies between latitudinal parallels of } 12^{\circ} 58^{\prime} 38^{\prime \prime} \mathrm{N} \text { and } 12^{\circ} 59^{\prime} 01^{\prime \prime} \mathrm{N} \\
\text { and longitudinal meridians of } 77^{\circ} 36^{\prime} 57^{\prime \prime} \mathrm{E} \text { and } 77^{\circ} 37^{\prime} 21^{\prime \prime} \mathrm{E}\end{array}$ \\
\hline
\end{tabular}

a [32]

${ }^{b}$ Google Earth Pro software

\section{Field collection of lake water and wastewater samples}

Collection of water column and sediment samples

The water column profile of UL, PU and NG lakes was established by collecting samples at varying depths (0.5 to 2.5 m, Fig. 2) during April-May 2019. The DO (dissolved oxygen measured using Eutech instruments, Highland Park, New Jersey, USA) and temperature probes were attached to the chain and ball assembly that facilitated in-situ measurements at desired depths. Water samples were collected to a maximum depth of $2.5 \mathrm{~m}$ (lake bed depth $=3.5 \mathrm{~m}$ from surface) at UL Lake, from $1.0 \mathrm{~m}$ depth (lake bed depth $=2.0 \mathrm{~m}$ ) at NG Lake and from $1.5 \mathrm{~m}$ depth (lake bed depth $=2.5 \mathrm{~m}$ ) at PU Lake. The water column profiles of UL, PU and NG lakes (Fig. 2) show that temperature, $\mathrm{pH}, \mathrm{DO}, \mathrm{TDS}$ and $\mathrm{HCO}_{3}{ }^{-}$values of a given lake vary insignificantly with depth indicative of a well-mixed system.
Sediments were collected at each lake (Figs. 3a to c) using Van Veen Grab sampler. The coordinates of the sampling points were recorded using a handheld GPS device (Garmin Etrex 30). The sediment samples were stored in labelled zip-lock covers. Both water and sediment samples were shipped at $4{ }^{\circ} \mathrm{C}$ and preserved at $4{ }^{\circ} \mathrm{C}$ in the laboratory.

\section{Collection of discharge samples}

PU lake has 7 discharge points (Fig. 3a); of these, PUIN1 is the outfall of a sewage treatment plant of a residential apartment complex [34]. The other 6 discharge points (PUIN2 to PUIN7) are outlets of stormwater drains. Stormwater outlets also discharged into UL lake (ULIN1 and ULIN2, Fig. 3b), NG lake (NGIN1 and NGIN2, Fig. 3c) and SK lake (SKIN1 to SKIN5, Fig. 3d).

As only PUIN1 and ULIN1 were active during the study period, samples were collected from these discharge points. Two samples were collected from PUIN1

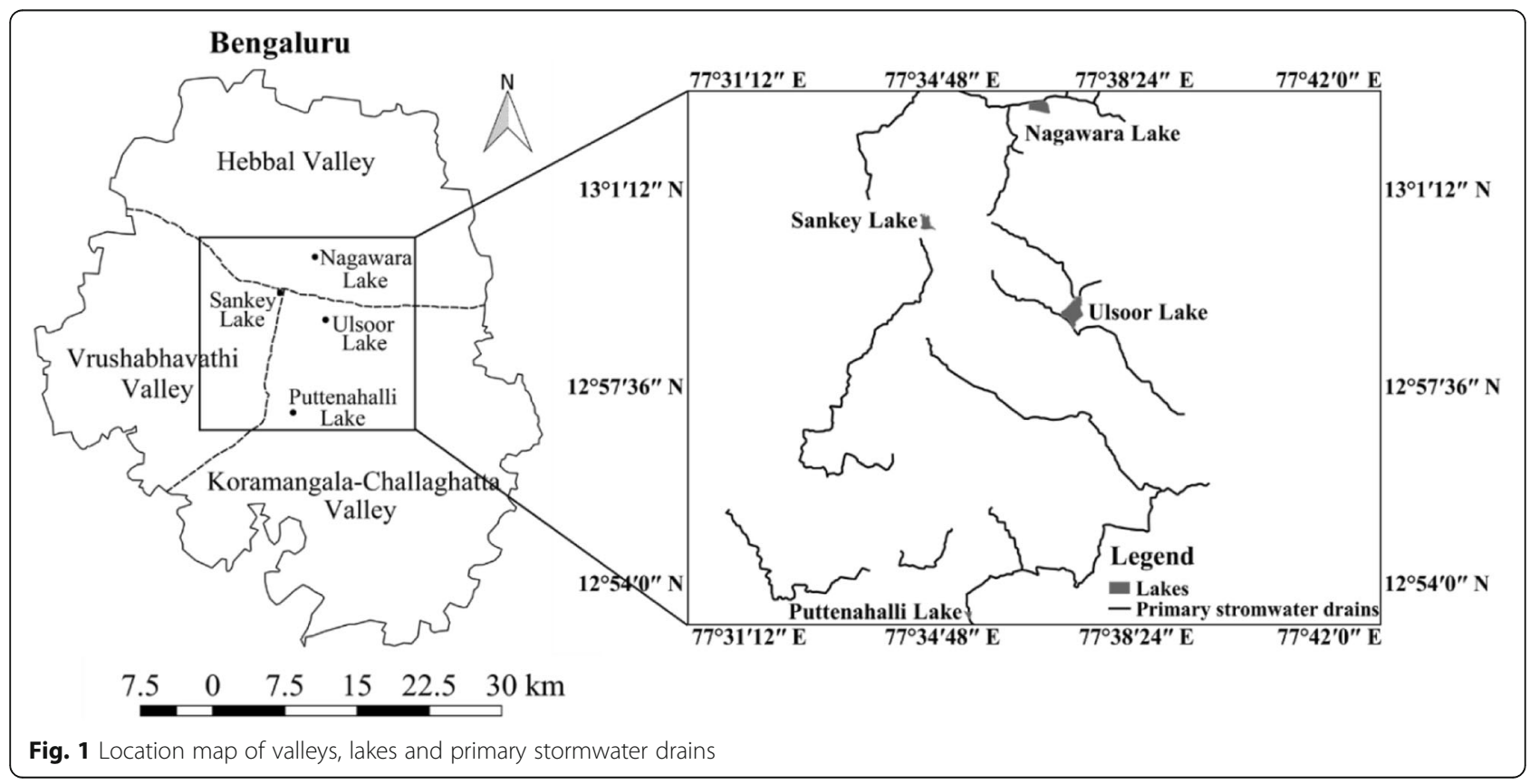


Parameter

(Temperatuire: ${ }^{\circ} \mathrm{C}$; $\mathrm{TDS} / \mathrm{DO} / \mathrm{HCO}_{3}{ }^{-}: \mathrm{mg} \mathrm{L}^{-1}$ )
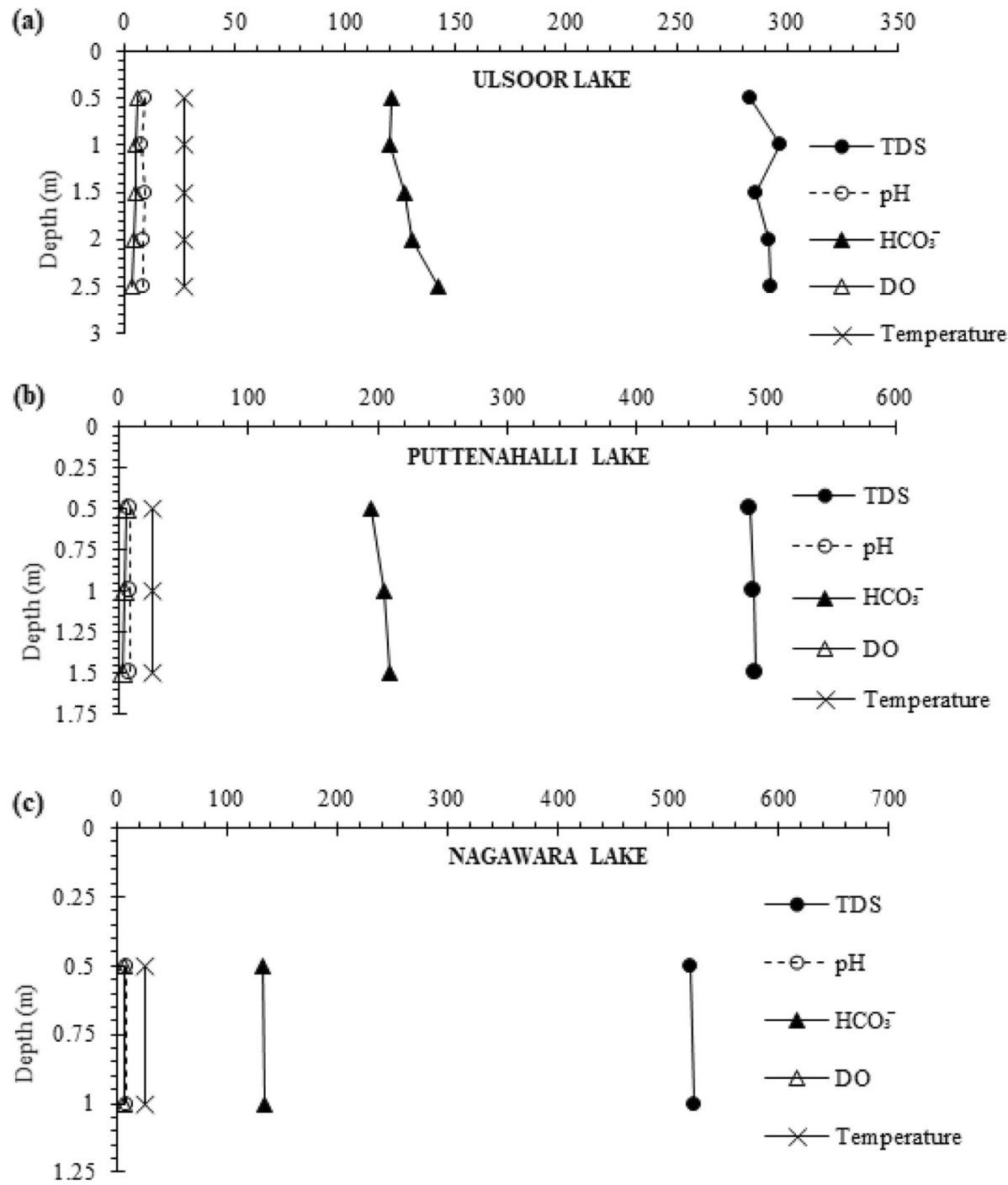

Fig. 2 Variation of physico-chemical parameters with depth of (a) Ulsoor lake (b) Puttenahalli lake and (c) Nagawara lake

(March and June 2018) with one sample collected from ULIN1 (June 2018). At each sampling location (PUIN1 and ULIN1), three, 1-L samples were collected for various analysis. Of the 3 samples, one sample was acidified with concentrated nitric acid for cation analysis, while, the two non-acidified samples were used for COD (Chemical Oxygen Demand), $\mathrm{NH}_{4}{ }^{+}$, and anion measurements.

\section{Collection of lake samples}

Nineteen grab samples were collected from the four lakes (Fig. 3) during January to June 2018. The sampling was performed between 09:00 and 15:00 $\mathrm{h}$ at all the lakes. The selection of sampling locations in a lake was guided by the availability of boat facility. Availability of boat facility for limited period restricted the number of samples that were collected from NG lake. Nonavailability of boat facility at SK lake confined the sampling to the lake periphery.

The sampling frequency of a given lake was guided by the occurrence of fish-kill event during the study period (January 2018 to June 2018); significant algal bloom is often associated with fish-kill. Samples were collected from PU lake in January (non-algal bloom condition) and March 2018 (fish kill was reported on 21 March 2018 [35]) at 10 locations (Fig. 3a). Likewise, samples were collected from UL lake in January 2018 and June 2018 (fish kill reported on 30 May 2018) at 6 locations (Fig. 3b). At SK and NG lakes, fish kill was not reported during the study period and hence the lakes were not re- 


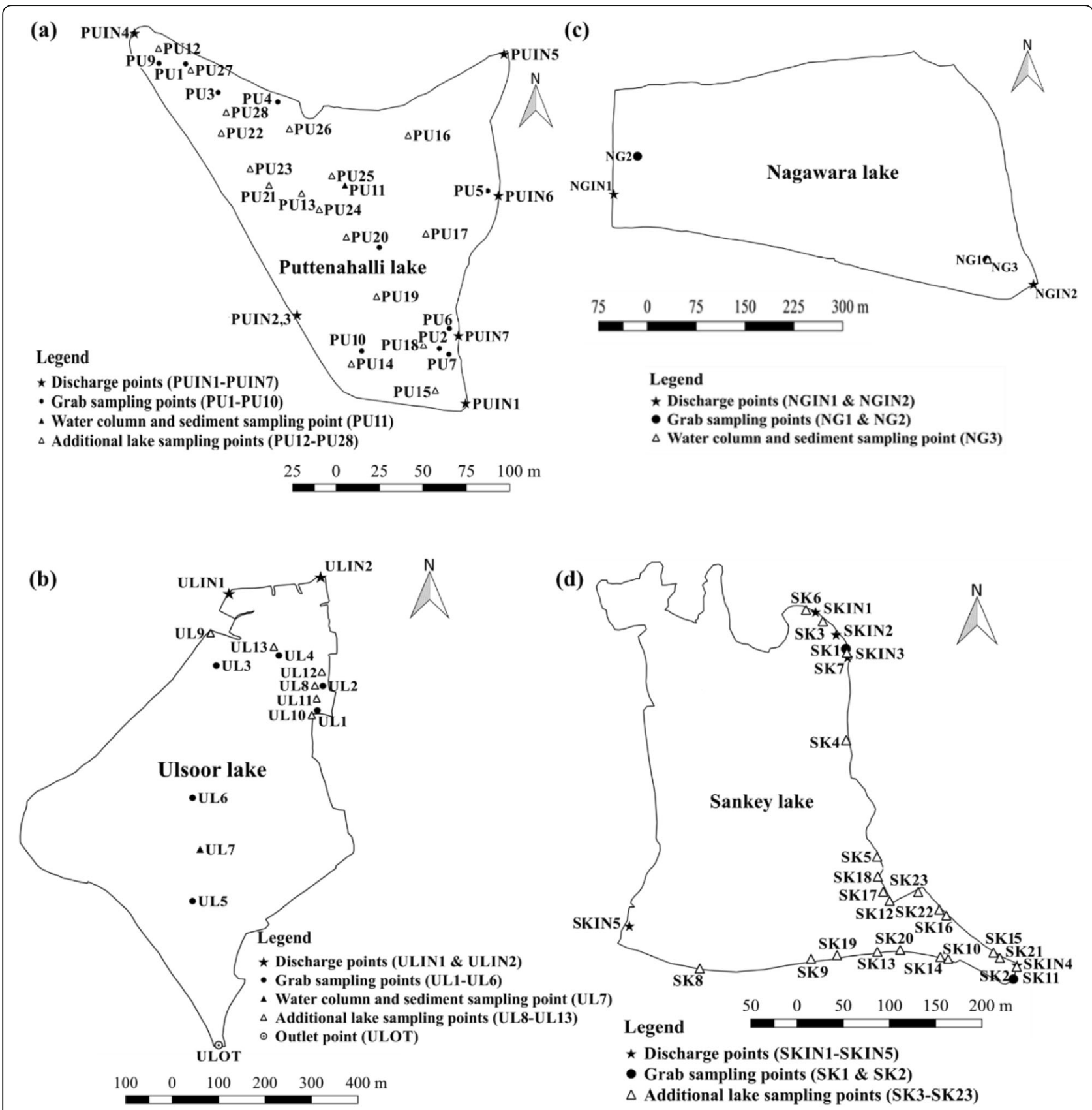

Fig. 3 Map of Bengaluru lakes with discharge and sampling points (a) Puttenahalli lake (b) Ulsoor lake (c) Nagawara lake and (d) Sankey lake

sample; grab samples were collected at 2 locations from NG lake (Fig. 3c) and at 2 locations from SK lake (Fig. 3d) in January 2018. Grab samples were collected at shallow depths $(15-90 \mathrm{~cm})$ from each lake using a stainless-steel bailer.

Five batches of water samples were collected at each sampling location of a given lake. Of the 5 batches, two samples were acidified with concentrated nitric acid for cation analysis, while, the three non-acidified samples were used for COD, $\mathrm{NH}_{4}{ }^{+}$, and anion measurements. All samples were shipped at $4{ }^{\circ} \mathrm{C}$ and preserved at $4{ }^{\circ} \mathrm{C}$ in the laboratory.

Besides sample collection during January 2018 to June 2018, additional sampling was performed at SK, PU and UL lakes, to monitor $\mathrm{pH}, \mathrm{DO}$ and TDS parameters. Samples were collected from twenty-one additional locations at SK lake in July 2018, September 2018, February 2019, April 2019 and May 2019. Likewise, samples were collected from six additional locations at UL lake in July 2018 and February 2019. Samples were collected from 
seventeen additional locations at PU lake in September 2018, April 2019 and May 2019. The additional sampling locations of PU lake (PU12 to PU28), UL lake (UL8 to UL13) and SK lake (SK3 to SK23) are included in Fig. $3 \mathrm{a}, \mathrm{b}$ and $\mathrm{d}$ respectively. Both lake and discharge samples were collected on dry days of the sampling period. The statistical distribution of measured parameters (Table 2) includes the data from additional sampling and water column profile of the lakes.

\section{Methods of analysis}

\section{Tests with grab and discharge samples}

Electrical conductivity (EC), $\mathrm{pH}$ and DO contents of lake water and discharge (PUIN1 and ULIN1) samples were measured in the field using portable $\mathrm{EC}, \mathrm{pH}$, and $\mathrm{DO}$ meters. All other parameters were measured in the laboratory. The EC values are represented as TDS using an appropriate relation. The COD concentrations of the lake water and PUIN1 and ULIN1 samples were determined with unfiltered samples using silver sulfatesulfuric acid closed reflux method [38]. The other parameters were measured with filtered $(0.45-\mu \mathrm{m}$ filter, Merck Millipore, USA) samples. The concentrations of $\mathrm{Mg}^{2+}, \mathrm{Ca}^{2+}, \mathrm{Na}^{+}$and $\mathrm{K}^{+}$ions and heavy metal ions $\left(\mathrm{Fe}^{2+}\right.$, $\mathrm{Mn}^{2+}, \mathrm{Cu}^{2+}, \mathrm{Pb}^{2+}, \mathrm{Zn}^{2+}, \mathrm{Al}^{3+}$ and $\left.\mathrm{Cd}^{2+}\right)$ in the acidified lake water and PUIN1 and ULIN1 samples were measured using atomic absorption spectrometer (Thermo AAS, ICE 3000, Thermo Fisher Scientific, Waltham, Massachusetts, USA).
The $\mathrm{NH}_{4}{ }^{+}$and anion concentrations were measured with non-acidified (filtered) samples. The $\mathrm{SO}_{4}{ }^{2-}$ ion concentration was measured [38] by turbidimetric method at $420 \mathrm{~nm}$ absorbance using UV-Visible spectrophotometer (Thermo Evolution 201, Thermo Fisher Scientific, Waltham, Massachusetts, USA). The $\mathrm{NO}_{3}{ }^{-}$and $\mathrm{NH}_{4}{ }^{+}$ ion concentrations were determined by ionchromatograph (Dionex ICS 2000, Thermo Fisher Scientific, Waltham, Massachusetts, USA). The $\mathrm{Cl}^{-}$and $\mathrm{HCO}_{3}{ }^{-} / \mathrm{CO}_{3}{ }^{2-}$ ion concentrations were determined using automatic titrator (Metrohm Titrino Plus 877, Metrohm AG, Herisau, Switzerland). The ionic ratio method helps to assess the role of mineral dissolution in influencing the ion composition of water samples. When weathering and dissolution of calcite, dolomite and gypsum significantly contribute to the chemical composition of water, the data points in $\left(\mathrm{Ca}^{2+}+\mathrm{Mg}^{2+}\right)$ versus $\left(\mathrm{HCO}_{3}{ }^{-}+\mathrm{SO}_{4}{ }^{2-}\right)$ chart will plot on/close to the 1:1 line [8]. Piper chart provides visualization of dominant cations and anions present in water samples. The chart reveals similarity and differences between water samples based on the hydrochemical facies. The $\mathrm{z}$ is function of lithology, solution kinetics and flow path of water [39].

Chlorophyll-a (Chl-a) concentrations in lake water samples were determined by the spectrophotometer method $[38,40]$ using $5 \mathrm{~L}$ samples. For Chl-a determination, appropriate aliquot of samples was concentrated by passing through Whatman GF/C filters. Prior to extraction, filters were homogenized to enhance extraction

Table 2 A statistical summary of measured parameters of lake and MWW samples

\begin{tabular}{|c|c|c|c|c|c|c|c|c|}
\hline \multirow[t]{2}{*}{ Parameter } & \multicolumn{3}{|c|}{ Mixed wastewater samples } & \multicolumn{3}{|c|}{ Lake samples } & \multirow[b]{2}{*}{$\begin{array}{l}\text { Average } \\
\text { values (mg } \\
L^{-1} \text { ) of } \\
\text { Bengaluru } \\
\text { city } \\
\text { groundwater } \\
\text { samples [36] }\end{array}$} & \multirow{2}{*}{$\begin{array}{l}\text { Average } \\
\text { values (mg } \\
\mathrm{L}^{-1} \text { ) of IISc } \\
\text { groundwater } \\
\text { samples [37] }\end{array}$} \\
\hline & Minimum & Median & $\overline{\text { Maximum }}$ & Minimum & Median & Maximum & & \\
\hline $\mathrm{pH}$ & 7.15 & 7.18 & 7.9 & 6.0 & 8.8 & 10.3 & - & - \\
\hline $\mathrm{HCO}_{3}^{-}\left(\mathrm{mg} \mathrm{L}^{-1}\right)$ & 109 & 305 & 551 & 80 & 109 & 344 & 341 & 165 \\
\hline $\mathrm{Cl}^{-}\left(\mathrm{mg} \mathrm{L}^{-1}\right)$ & 95 & 100 & 102 & 36 & 66 & 102 & 181 & 50 \\
\hline $\mathrm{SO}_{4}{ }^{2-}\left(\mathrm{mg} \mathrm{L}^{-1}\right)$ & 6 & 10 & 20 & 7 & 40 & 319 & 88 & 12 \\
\hline $\mathrm{NO}_{3}^{-}\left(\mathrm{mg} \mathrm{L}^{-1}\right)$ & 0.5 & 0.7 & 2.5 & 0.0 & 3.5 & 9.0 & 53.0 & - \\
\hline $\mathrm{Ca}^{2+}\left(\mathrm{mg} \mathrm{L}^{-1}\right)$ & 46 & 53 & 78 & 17 & 25 & 90 & 117 & 38 \\
\hline $\mathrm{Mg}^{2+}\left(\mathrm{mg} \mathrm{L}^{-1}\right)$ & 20 & 20 & 24 & 7 & 14 & 40 & 53 & 15 \\
\hline $\mathrm{Na}^{+}\left(\mathrm{mg} \mathrm{L}^{-1}\right)$ & 73 & 87 & 95 & 20 & 57 & 92 & 97 & 39 \\
\hline $\mathrm{K}^{+}\left(\mathrm{mg} \mathrm{L}^{-1}\right)$ & 17 & 19 & 20 & 8 & 13 & 16 & 6 & - \\
\hline $\mathrm{NH}_{4}^{+}\left(\mathrm{mg} \mathrm{L}^{-1}\right)$ & 16 & 29 & 50 & 0.0 & 0.0 & 4 & - & - \\
\hline TDS $\left(\mathrm{mg} \mathrm{L}^{-1}\right)$ & 591 & 683 & 811 & 173 & 359 & 882 & 770 & 234 \\
\hline $\operatorname{COD}\left(\mathrm{mg} \mathrm{L}^{-1}\right)$ & 54 & 83 & 99 & 12 & 42 & 67 & - & - \\
\hline $\mathrm{DO}\left(\mathrm{mg} \mathrm{L}^{-1}\right)$ & 0.1 & 0.4 & 0.5 & 4.1 & 7.5 & 15.0 & - & - \\
\hline Chl-a $\left(\mu \mathrm{g} \mathrm{L}^{-1}\right)$ & - & - & - & $\mathrm{BDL}$ & 4 & 19 & - & - \\
\hline
\end{tabular}


efficiency. Extraction was performed using 90\% acetone followed by centrifugation to produce a supernatant for spectrophotometric determination. The absorbance was recorded at four different wavelengths $(630,645,665$ and $750 \mathrm{~nm}$ ) for measuring Chl-a concentration. The detection limit of the method is $0.02 \mu \mathrm{g} \mathrm{L}^{-1}$. Trophic state index (TSI) based on Chl-a concentration is calculated to assess lake's trophic state in the terms of algal productivity. Trophic state indicates anthropogenic influence on water quality and the ecological functioning of lakes. The scale of TSI ranges from 0 to 100. Each major division represents a doubling in algal biomass. The index number can be calculated from any of several parameters, including Secchi disk transparency, chlorophyll, and total phosphorus [41].

The COD concentrations of PUIN1 (treated sewage) and ULIN1 (stormwater runoff) samples (Table 2) range from 54 to $99 \mathrm{mg} \mathrm{L}^{-1}$ (median $=83 \mathrm{mg} \mathrm{L}^{-1}$ ). The DO concentrations range from 0.10 to $0.48 \mathrm{mg} \mathrm{L}^{-1}$ (median $=0.42 \mathrm{mg} \mathrm{L}^{-1}$ ) and $\mathrm{NH}_{4}{ }^{+}$ion concentrations range from 16 to $50 \mathrm{mg} \mathrm{L}^{-1}$ (median $=29 \mathrm{mg} \mathrm{L}^{-1}$ ). The anoxic nature of the samples hindered the oxidation of $\mathrm{NH}_{4}{ }^{+}$ ions resulting in low concentrations of $\mathrm{NO}_{3}{ }^{-}$ions. Based on the COD, DO and $\mathrm{NH}_{4}{ }^{+}$concentrations, the stormwater runoffs and treated sewage discharging into the Bengaluru lakes are referred as mixed wastewater $(\mathrm{MWW})$ in further discussions.

\section{Tests with sediment samples}

The gravimetric moisture content of the sediments was determined by oven-drying them at $105^{\circ} \mathrm{C}$ for $24 \mathrm{~h}$. The organic matter of the sediments was determined by Walkley Black method. The EC was determined by agitating the sediments with ultra-pure water (sediment: water ratio $=1: 2.5)$ for $60 \mathrm{~min}$. After centrifugation, the EC of supernatant was measured and converted to TDS values. Water leaching tests were performed with the lake sediments in accordance with ASTM procedure [42]. The water leachate was examined for $\mathrm{Ca}^{2+}, \mathrm{Mg}^{2+}$, $\mathrm{Na}^{+}, \mathrm{K}^{+}, \mathrm{Cl}^{-}, \mathrm{HCO}_{3}{ }^{-}$and $\mathrm{SO}_{4}{ }^{-}$ions by the previously described procedures.

The sediment residue from water leaching test was agitated again with ultra-pure water $(200 \mathrm{~mL})$ for $2 \mathrm{~h}$ to remove residual salts. The suspension was centrifuged, and the EC of the washings ranged between 25 and 45 $\mu \mathrm{S} \mathrm{cm}{ }^{-1}$. The exchangeable cation content of the moistwashed residue was determined using ammonium acetate extraction method [43]. The concentrations of displaced $\mathrm{Ca}^{2+}, \mathrm{Mg}^{2+}, \mathrm{Na}^{+}, \mathrm{K}^{+}$ions in the ammonium acetate extracts were estimated using atomic absorption spectrometer. Corrections were applied for residual cation concentrations persisting in the moist-washed sediments.

\section{Results and discussion}

\section{Chemical composition of lake water samples}

Table 2 summarizes the statistical distribution of chemical parameters of the lake and MWW samples. The lake samples are characterized with median $\mathrm{pH}$ of 8.8. The median cation concentrations of the lake samples vary as: $\mathrm{Na}^{+}>\mathrm{Ca}^{2+}>\mathrm{Mg}^{2+} \approx \mathrm{K}^{+}>\mathrm{NH}_{4}{ }^{+}$. Likewise, the median anion concentrations vary as: $\mathrm{HCO}_{3}{ }^{-}>\mathrm{Cl}^{-}>\mathrm{SO}_{4}{ }^{2-}>$ $\mathrm{NO}_{3}{ }^{-}$. The lake samples showed measurable concentrations of $\mathrm{Al}^{3+}$ and $\mathrm{Zn}^{2+}$ ions, while, the strengths of other heavy metal ions $\left(\mathrm{Fe}^{2+}, \mathrm{Mn}^{2+}, \mathrm{Cu}^{2+}, \mathrm{Pb}^{2+}\right.$ and $\left.\mathrm{Cd}^{2+}\right)$ were below the detection limit of the instrument $(<0.01 \mathrm{mg}$ $\mathrm{L}^{-1}$ ). The $\mathrm{Al}^{3+}$ ion concentrations in the lake samples ranged from 0.14 to $0.39 \mathrm{mg} \mathrm{L}^{-1}$; further, the $\mathrm{Al}^{3+}$ ion concentrations of twelve samples were greater than its permissible limit [44] in drinking water $\left(0.2 \mathrm{mg} \mathrm{L}^{-1}\right)$. The MWW samples did not show the presence of $\mathrm{Al}^{3+}$ ions. It is hence likely that dissolution of oxide coatings on particle surfaces and/or dissolution of mineral particle edges by humic acid are possibly responsible for presence of $\mathrm{Al}^{3+}$ ions in the lake samples [45]. The $\mathrm{Zn}^{2+}$ ion concentrations in the lake samples ranged from 0.011 to $0.081 \mathrm{mg} \mathrm{L}^{-1}$ and are below the permissible limit in drinking water $\left[15 \mathrm{mg} \mathrm{L}^{-1}\right.$; 44]. Comparatively, the $\mathrm{Zn}^{2+}$ ion concentrations in the MWW samples ranged between 0.032 to $0.035 \mathrm{mg} \mathrm{L}^{-1}$.

\section{Multiple correlation analysis}

The lake water data was analysed for multiple correlations among the measured variables (Table 3). The strong positive correlation between $\mathrm{DO}$ and $\mathrm{pH}(R=$ 0.74) is attributed to the production of $\mathrm{DO}$ and $\mathrm{OH}^{-}$ ions during intense photosynthesis activity. Likewise, the strong negative correlation $(R=-0.72)$ between $\mathrm{pH}$ and $\mathrm{HCO}_{3}{ }^{-}$ions arises from bicarbonate consumption and release of $\mathrm{OH}^{-}$ions during intense algal photosynthetic activity $[19,22]$. The strong negative correlation between $\mathrm{Ca}^{2+}$ and $\mathrm{Mg}^{2+}$ ion concentrations with $\mathrm{pH}(R=-0.64$ to -0.62$)$ apparently arise as the alkaline $\mathrm{pH}$ reduces the divalent cation concentrations from carbonate precipitation reactions (discussed in section 4.3.2). The strong positive correlation $(R=0.69)$ between $\mathrm{pH}$ and $\mathrm{CO}_{3}{ }^{2-}$ ions is attributed to $\mathrm{HCO}_{3}{ }^{-}$to $\mathrm{CO}_{3}{ }^{2-}$ transformation in the alkaline $\mathrm{pH}$ environment $(\mathrm{pH} \geq 8.35)$. The strong correlation between $\mathrm{Ca}^{2+}$ and $\mathrm{HCO}_{3}{ }^{-}$ions arises from their tendency to form calcium carbonate in an alkaline $\mathrm{pH}$ environment. The strong correlation between $\mathrm{Ca}^{2+}$ and $\mathrm{SO}_{4}{ }^{2-}$ ions is attributed to dissolution of anthropogenic gypsum. The positive correlation between $\mathrm{Chl}-\mathrm{a}$ and $\mathrm{pH}(R=0.74)$ supports the hypothesis that algal photosynthesis renders the lake water alkaline. The positive correlation between Chl-a and DO $(R=0.59)$ is attributed to production of DO by photosynthetic algae. The negative correlation between $\mathrm{Chl}-\mathrm{a}$ and $\mathrm{HCO}_{3}{ }^{-}$ions 
Table 3 Multiple correlation analysis for grab samples

\begin{tabular}{|c|c|c|c|c|c|c|c|c|c|c|c|c|c|}
\hline- & TDS & $\mathrm{pH}$ & $\mathrm{CO}_{3}{ }^{2-}$ & $\mathrm{HCO}_{3}{ }^{-}$ & $\mathrm{Cl}^{-}$ & $\mathrm{SO}^{2-}$ & $\mathrm{NO}_{3}^{-}$ & $\mathrm{Ca}^{2+}$ & $\mathrm{Mg}^{2+}$ & $\mathrm{Na}^{+}$ & $\mathrm{K}^{+}$ & DO & Chl-a \\
\hline TDS & 1 & & & & & & & & & & & & \\
\hline $\mathrm{pH}$ & -0.06 & 1 & & & & & & & & & & & \\
\hline $\mathrm{CO}_{3}^{2-}$ & -0.14 & 0.69 & 1 & & & & & & & & & & \\
\hline $\mathrm{HCO}_{3}^{-}$ & 0.49 & -0.72 & -0.57 & 1 & & & & & & & & & \\
\hline $\mathrm{Cl}^{-}$ & 0.25 & 0.25 & 0.68 & 0.12 & 1 & & & & & & & & \\
\hline $\mathrm{SO}_{4}{ }^{2-}$ & 0.32 & -0.59 & -0.59 & 0.71 & -0.05 & 1 & & & & & & & \\
\hline $\mathrm{NO}_{3}{ }^{-}$ & 0.45 & -0.58 & -0.79 & 0.64 & -0.43 & 0.77 & 1 & & & & & & \\
\hline $\mathrm{Ca}^{2+}$ & 0.36 & -0.64 & -0.29 & 0.87 & 0.30 & 0.67 & 0.50 & 1 & & & & & \\
\hline $\mathrm{Mg}^{2+}$ & 0.61 & -0.62 & -0.36 & 0.86 & 0.16 & 0.69 & 0.61 & 0.84 & 1 & & & & \\
\hline $\mathrm{Na}^{+}$ & 0.19 & 0.39 & 0.63 & 0.06 & 0.90 & -0.04 & -0.37 & 0.27 & 0.06 & 1 & & & \\
\hline $\mathrm{K}^{+}$ & -0.06 & 0.19 & 0.43 & 0.04 & 0.73 & 0.14 & -0.36 & 0.29 & -0.03 & 0.81 & 1 & & \\
\hline DO & -0.12 & 0.74 & 0.73 & -0.71 & 0.42 & -0.66 & -0.72 & -0.57 & -0.68 & 0.47 & 0.33 & 1 & \\
\hline Chl-a & 0.10 & 0.74 & 0.44 & -0.51 & 0.27 & -0.20 & -0.27 & -0.42 & -0.47 & 0.36 & 0.30 & 0.59 & 1 \\
\hline
\end{tabular}

is attributed to consumption of bicarbonate ions by algae.

Chl-a concentrations in the lake samples during nonalgal bloom condition ranged from $<0.02$ to $0.022 \mu \mathrm{g}$ $\mathrm{L}^{-1}$ (PU1 \& PU2, SK1 \& SK2; Table 3). Comparatively, Chl-a concentrations in the lake samples are significantly higher during algal bloom condition and ranged from 2.8 to $18.8 \mathrm{\mu g} \mathrm{L}^{-1}$ (PU3-PU10, NG2, UL1-UL6; Table $3)$. The TSI of the lakes is estimated from Chl-a values using the equation $[41,46]$,

$$
\operatorname{TSI}(C h l-a)=9.81 \ln (C h l-a)+30.6
$$

Values of TSI $<30$ corresponds to oligotrophic state and values of TSI $>50$ corresponds to eutrophic state [46]. The TSI values of majority (13 out of 19) of lake samples range between 41 to 59 (Table 4) indicative of near eutrophic or eutrophic state. The eutrophic status of the lakes supports the hypothesis that photosynthetic metabolism of algae is responsible for strong correlations between the lake parameters (Table 3).

Eutrophic state indicates substantial growth of algal population which can disrupt the DO regime of the lake. Substantial algal growth causes oxygen supersaturation during photosynthetic period (maximum DO concentration $=15 \mathrm{mg} \mathrm{L}^{-1}$; Table 2) and decrease in DO during night time because of algal respiration. Periods of oxygen supersaturation is detrimental and leads to fish mortality [47]; and hypoxia caused by algal bloom collapse is often associated with fish kill [48].

\section{Anthropogenic influence on major ion composition of Bengaluru lakes}

Table 2 includes the average composition of major ions in the groundwater of Bengaluru city [36] and Indian
Institute of Science (IISc) campus, Bengaluru [37]. The major cation and anion concentrations of IISc groundwater samples are $0.36-0.53$ and $0.29-0.61$ times lower than those of the Bengaluru city groundwater samples and are 0.14 to 0.72 times lower than the median cation concentrations of MWW samples (Table 2). The major anion concentrations of IISc groundwater samples are

Table 4 Trophic state of Bengaluru lakes

\begin{tabular}{|c|c|c|c|}
\hline Sample ID & Chl-a $\left(\mu \mathrm{g} \mathrm{L}^{-1}\right)$ & TSI (Chl-a) & Trophic state ${ }^{a}$ \\
\hline PU1 & $<0.02$ & 0 & Oligotrophic \\
\hline PU2 & 0.022 & 0 & Oligotrophic \\
\hline PU3 & 9.7 & 53 & Eutrophic \\
\hline PU4 & 3.7 & 43 & Near eutrophic \\
\hline PU5 & 5.9 & 48 & Near eutrophic \\
\hline PU6 & 5.7 & 48 & Near eutrophic \\
\hline PU7 & 7.8 & 51 & Eutrophic \\
\hline PU8 & 10.9 & 54 & Eutrophic \\
\hline PU9 & 4.3 & 45 & Near eutrophic \\
\hline PU10 & 17.2 & 59 & Eutrophic \\
\hline UL1 & 5.0 & 46 & Near eutrophic \\
\hline UL2 & - & - & - \\
\hline UL3 & - & - & - \\
\hline UL4 & 3.8 & 44 & Near eutrophic \\
\hline UL5 & 3.3 & 42 & Near eutrophic \\
\hline UL6 & 2.8 & 41 & Near eutrophic \\
\hline NG1 & - & - & - \\
\hline NG2 & 18.8 & 59 & - \\
\hline SK1 & 0.021 & 0 & - \\
\hline SK2 & $<0.02$ & 0 & - \\
\hline
\end{tabular}

a Tropic state of NG and SK lakes are not stated as number of sampling points are restricted and not spatially distributed 
0.50 to 0.55 times lower than the median anion concentrations of MWW samples. The $\mathrm{SO}_{4}{ }^{2-}$ concentrations of IISc groundwater samples and MWW samples are however comparable (10 and $11.5 \mathrm{mg} \mathrm{L}^{-1}$ ).

Besides $\mathrm{K}^{+}$and $\mathrm{Na}^{+}$ions, the concentrations of $\mathrm{Ca}^{2+}$, $\mathrm{Mg}^{2+}, \mathrm{Cl}^{-}, \mathrm{SO}_{4}{ }^{2-}$ and $\mathrm{HCO}_{3}{ }^{-}$ions in Bengaluru city groundwater samples are higher than the median MWW values (Table 2). The groundwater in IISc campus is unpolluted as there is no wastewater contamination on the campus. The major ion composition of IISc groundwater samples is considered as representative of non-polluted water source in Bengaluru city. Lithology, weathering of drainage catchment, and rainwater contribute 57 to $98 \%$ of $\mathrm{Ca}^{2+}, \mathrm{Mg}^{2+}, \mathrm{Na}^{+}, \mathrm{K}^{+}, \mathrm{HCO}_{3}{ }^{-}, \mathrm{SO}_{4}{ }^{2-}$ and $\mathrm{Cl}^{-}$ion concentrations of unpolluted water source; human activity contributes the remaining 2 to $43 \%$ [49]. Geogenic and anthropogenic contributions to the major ion composition of the two sets of groundwater samples are compared in Table 5. The anthropogenic component ratio is calculated as:

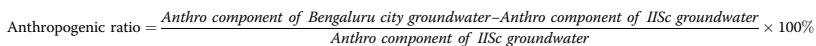

The ratios (Table 5) indicate that anthropogenic component of Bengaluru city groundwater samples is 540 to $5333 \%$ larger than the corresponding component of IISc groundwater samples. The total annual rainfall of Bengaluru city is $831 \mathrm{~mm}$. The aquifer depths in Bengaluru city range from 3.12 to $21.35 \mathrm{~m}$ during monsoon (median value $=7.07 \mathrm{~m}$ ) and range from 4.8 to 22.01 in the post-pre-monsoon season (median value $=9.8 \mathrm{~m}$ ) [30]. The main rock formation in the study area is the peninsular gneiss complex, represented by mafic gneiss, biotite gneiss, granodioritic gneiss with intrusions like dykes, and pegmatite. Physical and chemical weathering of the parent rocks form overburden material of varying thickness between the surface and the aquifer. The drainage characteristics of the overburden is function of soil texture, topography, profile development presence of impervious strata and depth of water table. Based on the above parameters, the drainage of the overburden ranges from excellent ( 1 to $10^{-3} \mathrm{~cm} \mathrm{~s}^{-1}$ ) to poor $\left(10^{-4}\right.$ to $\left.10^{-6} \mathrm{~cm} \mathrm{~s}^{-1}\right)$. Owing to the smooth rolling topography of peninsular gneissic terrain. The region exhibits flat (0 to $3 \%)$, medium (3-7\%) and steep (> $7 \%)$ slopes [50]. Occurrence of zones of poor drainage, flat slopes and shallow groundwater makes the Bengaluru aquifers vulnerable to anthropogenic pollution.

Fig. 4 plots the total cation $\left(\mathrm{TZ}^{+}, \mathrm{mN}\right)$ versus $\mathrm{HCO}_{3}{ }^{-}$ ion concentrations of the lake samples. The data points plot below the 1:1 line imply that the major ion composition of the lake samples is influenced by anthropogenic activities than by the lithology of the drainage catchments [51]. If the major ion composition of Bengaluru lakes was dominated by products of silicate and carbonate weathering, the data points would plot on or close to the $1: 1$ line [8].

The influence of anthropogenic contamination on the major ion composition of the lakes is examined in the Piper chart (Fig. 5). The diagram shows that the nonpolluted IISc groundwater samples dominate in $\mathrm{Ca}^{2+}$ and $\mathrm{HCO}_{3}{ }^{-}$ions, while the polluted lake samples show dominance of $\mathrm{Mg}^{2+}, \mathrm{Na}^{+}, \mathrm{K}^{+}, \mathrm{Cl}^{-}$and $\mathrm{SO}_{4}{ }^{2-}$ ions. Therefore, while, the IISc samples classify as $\mathrm{Ca}-\mathrm{HCO}_{3}$ type, the lake samples classify as mixed $\mathrm{Ca}-\mathrm{Na}-\mathrm{HCO}_{3}$ and mixed $\mathrm{Ca}-\mathrm{Mg}-\mathrm{Cl}$ types. Enrichment of $\mathrm{Mg}^{2+}, \mathrm{Na}^{+}$and $\mathrm{Cl}^{-}$ions from anthropogenic contamination alters the chemical-type of the lake water. The ionic ratio method (Fig. 4) and Piper chart (Fig. 5) are thus useful tools to understand how factors other than mineral dissolution and hydrochemical facies can impact the chemical composition of water bodies.

\section{Sodium and chloride ions}

The variation of $\mathrm{Na}^{+} / \mathrm{Cl}^{-}$molar ratio with EC develops as horizontal scatter (Fig. 6), implying that water

Table 5 Geogenic and anthropogenic contributions to major ion composition of groundwater samples

\begin{tabular}{|c|c|c|c|c|c|c|c|}
\hline \multirow[t]{2}{*}{ Ion $\left(\mathrm{mg} \mathrm{L}^{-1}\right)$} & \multicolumn{3}{|c|}{ Bengaluru city groundwater samples [36] } & \multicolumn{3}{|c|}{ IISc groundwater samples [37] } & \multirow{2}{*}{$\begin{array}{l}\text { Anthropogenic } \\
\text { components } \\
\text { ratio }(\%)^{a}\end{array}$} \\
\hline & $\begin{array}{l}\text { Average value } \\
\left(\mathrm{mg} \mathrm{L}^{-1}\right)\end{array}$ & $\begin{array}{l}\text { Geogenic } \\
\text { component }\end{array}$ & $\begin{array}{l}\text { Anthropogenic } \\
\text { component }\end{array}$ & $\begin{array}{l}\text { Average value } \\
\left(\mathrm{mg} \mathrm{L}^{-1}\right)\end{array}$ & $\begin{array}{l}\text { Geogenic } \\
\text { component }\end{array}$ & $\begin{array}{l}\text { Anthropogenic } \\
\text { component }\end{array}$ & \\
\hline $\mathrm{HCO}_{3}^{-}$ & 341.0 & 161.7 & 179.3 & 165 & 161.7 & 3.3 & 5333 \\
\hline $\mathrm{Cl}^{-}$ & 181.0 & 14.9 & 166.1 & 49.7 & 14.9 & 34.8 & 377 \\
\hline $\mathrm{SO}_{4}{ }^{2-}$ & 88.0 & 5.1 & 82.9 & 11.8 & 5.1 & 6.7 & 1133 \\
\hline $\mathrm{Ca}^{2+}$ & 117.0 & 34.6 & 82.4 & 38 & 34.6 & 3.4 & 2310 \\
\hline $\mathrm{Mg}^{2+}$ & 53.0 & 13.6 & 39.4 & 14.8 & 13.6 & 1.2 & 3226 \\
\hline $\mathrm{Na}^{+}$ & 970.0 & 27.8 & 69.2 & 38.6 & 27.8 & 10.8 & 540 \\
\hline $\mathrm{K}^{+}$ & 0 & - & 5.6 & - & 0 & - & \\
\hline
\end{tabular}

${ }^{\mathrm{a}}$ Eq. (2) 


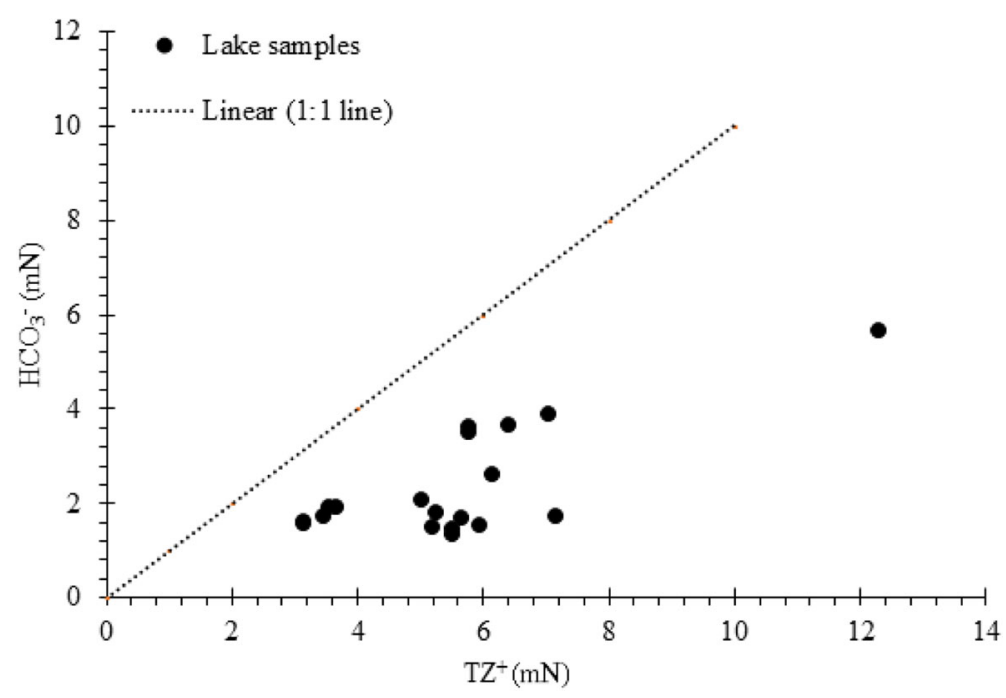

Fig. 4 Total cation concentration $\left(\mathrm{TZ}^{+}\right)$as a function of $\mathrm{HCO}_{3}{ }^{-}$ion concentration of lake samples

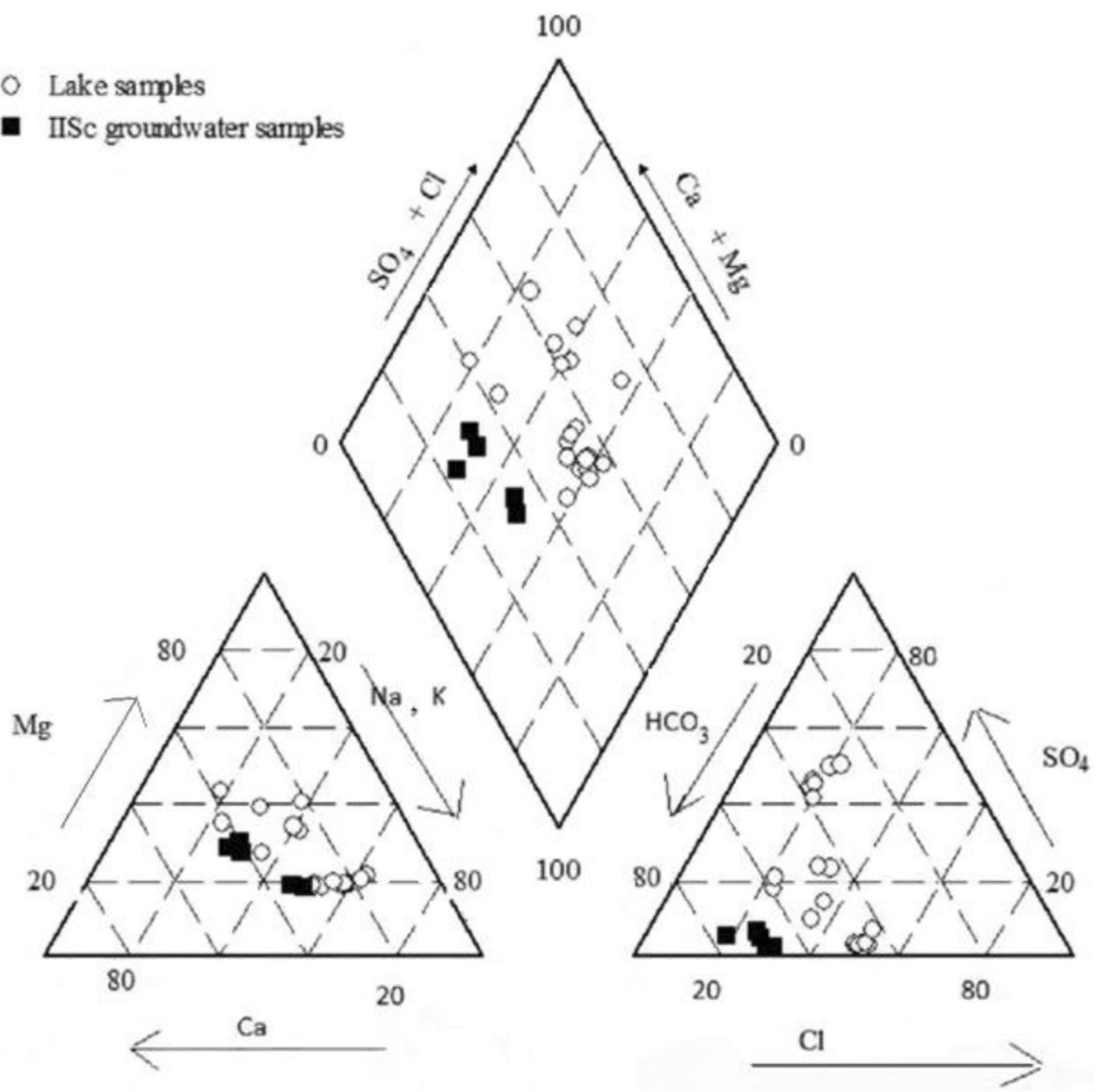

Fig. 5 Piper plot for lake and IISC groundwater samples: Scale is expressed as \% 


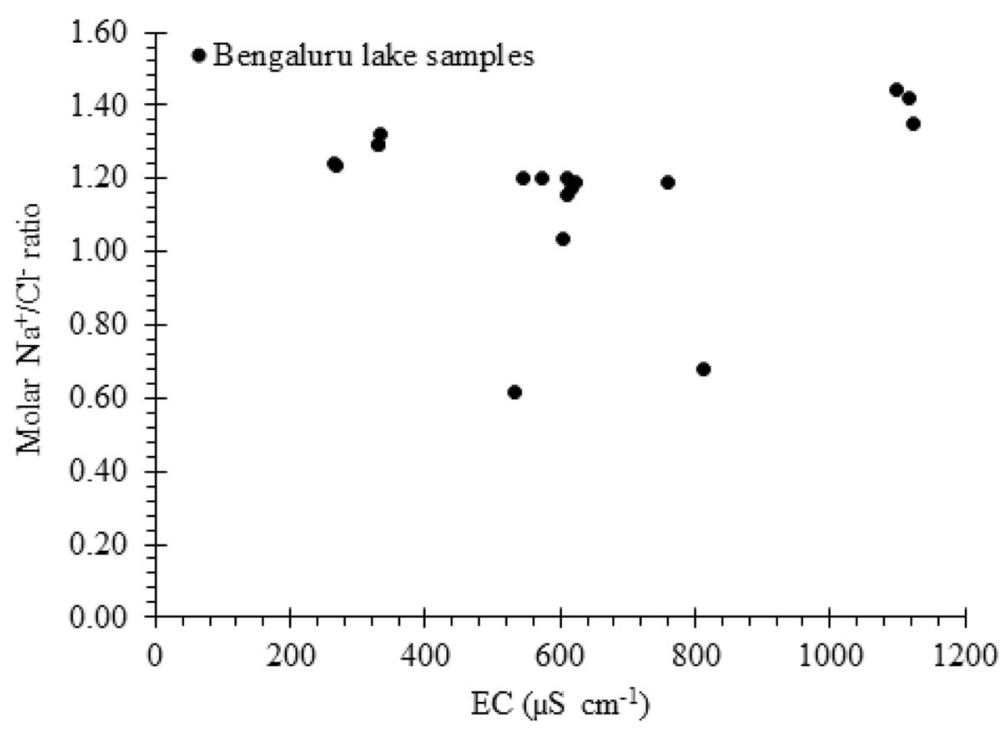

Fig. 6 Variation of $\mathrm{Na}^{+} / \mathrm{Cl}^{-}$molar ratio with electrical conductivity (EC) for Bengaluru lake samples

evaporation during dry season strongly impacts the $\mathrm{Na}$ $\mathrm{Cl}$ balance in the lakes [8]. Seventy four percent of the lake samples exhibit $\mathrm{Na}^{+} / \mathrm{Cl}^{-}$molar ratios ranging from 0.62 to 1.29 with median value of 1.2 , while $26 \%$ samples exhibit molar ratios ranging from 1.32 to 1.46. Loss of chloride as gaseous $\mathrm{HCl}$ is apparently responsible for $\mathrm{Na}^{+} / \mathrm{Cl}^{-}$ratios being greater than unity. $\mathrm{HCl}_{\text {(gas) }}$ is formed from the reaction between sodium chloride $(\mathrm{NaCl})$ and hydrogen ions in the lake water as [52]:

$$
\mathrm{NaCl}+\mathrm{H}^{+} \rightarrow \mathrm{Na}^{+}+\mathrm{HCl}_{\text {gas }}
$$

The Gibb's diagram (Fig. 7) shows that rock weathering dominates the chemical composition of IISc groundwater samples. Comparatively, evaporation process tends to influence the chemical composition of the lake water samples.

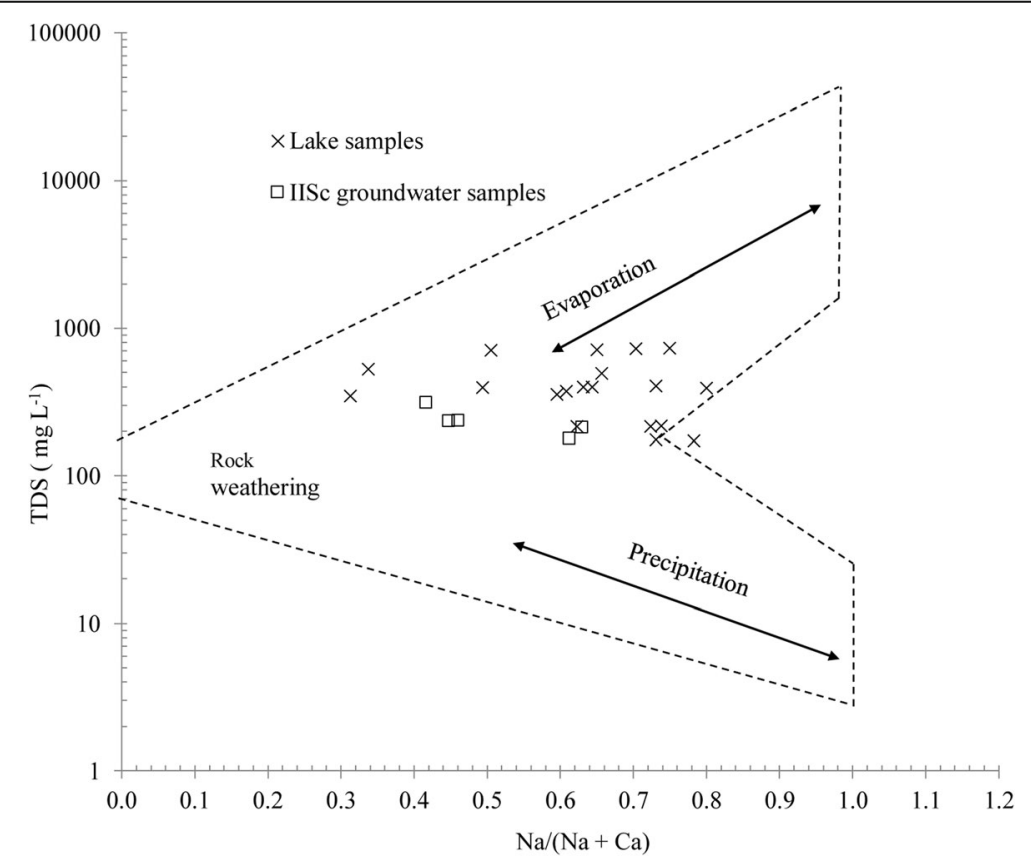

Fig. 7 Gibb's diagram of lake and IISc groundwater samples 


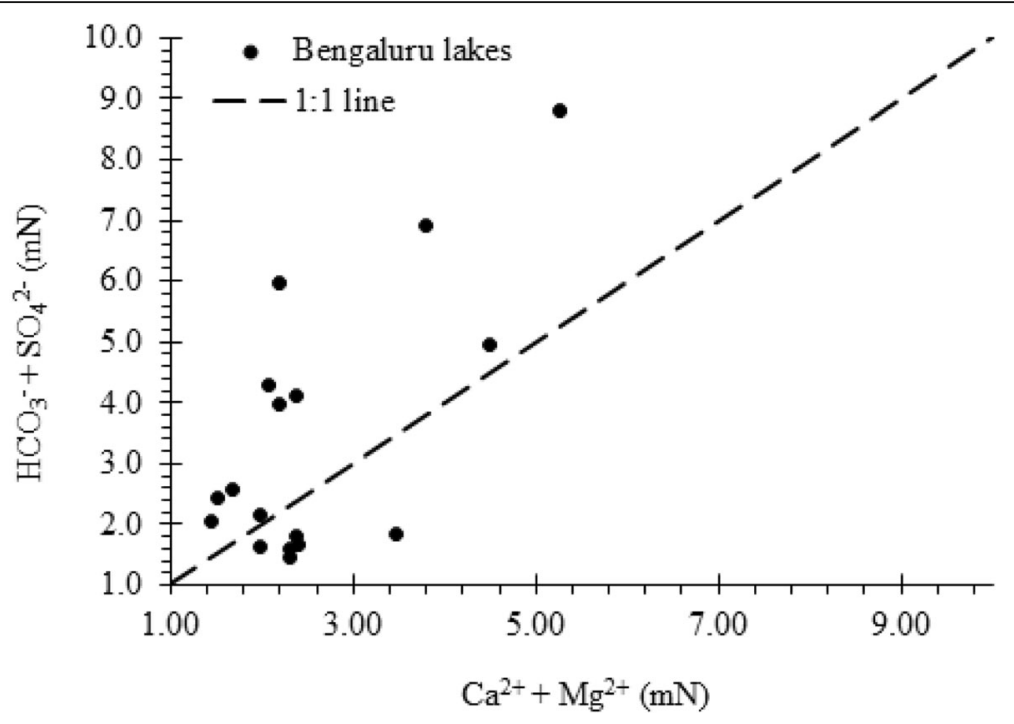

Fig. 8 Variation of $\left(\mathrm{Ca}^{2+}+\mathrm{Mg}^{2+}\right)$ with $\left(\mathrm{SO}_{4}{ }^{2-}+\mathrm{HCO}_{3}{ }^{-}\right)$of Bengaluru lake samples

\section{Calcium, magnesium, bicarbonate, sulfate}

The $\left(\mathrm{Ca}^{2+}+\mathrm{Mg}^{2+}\right)$ vs. $\left(\mathrm{HCO}_{3}{ }^{-}+\mathrm{SO}_{4}{ }^{2-}\right)$ chart can reveal the role of mineral dissolution and ion-exchange reactions in controlling the chemical composition of water sources $[51,53]$. If the data points are located on the 1:1 line, calcite and gypsum mineral dissolution predominantly contribute to the lake water chemistry. If majority of data points plot in the $\left(\mathrm{Ca}^{2+}+\mathrm{Mg}^{2+}\right)$ sector, it is implied that reverse ionexchange enhances the divalent cation concentration in the water. The $\left(\mathrm{Ca}^{2+}+\mathrm{Mg}^{2+}\right)$ vs. $\left(\mathrm{HCO}_{3}{ }^{-}+\mathrm{SO}_{4}{ }^{2-}\right)$ chart (Fig. 8) of Bengaluru lake samples show that majority of data points are located in the $\left(\mathrm{HCO}_{3}{ }^{-}+\mathrm{SO}_{4}{ }^{2-}\right)$ segment, implying a deficit of divalent cations in the lake samples.
The saturation index (SI) represents the equilibrium condition between solution and mineral and is calculated as:

$$
S I=\log 10 \frac{I A P}{K s p}
$$

In Eq. (4), IAP represents the ion activity product of the dissociated chemical species and $K_{\mathrm{sp}}$ represents the equilibrium solubility product of the mineral. Calculations of SI of carbonate minerals of a lake water sample at median $\mathrm{pH}$ (8.8) showed that the lake is oversaturated $(\mathrm{SI}>0)$ with carbonate mineral (Fig. 9). The

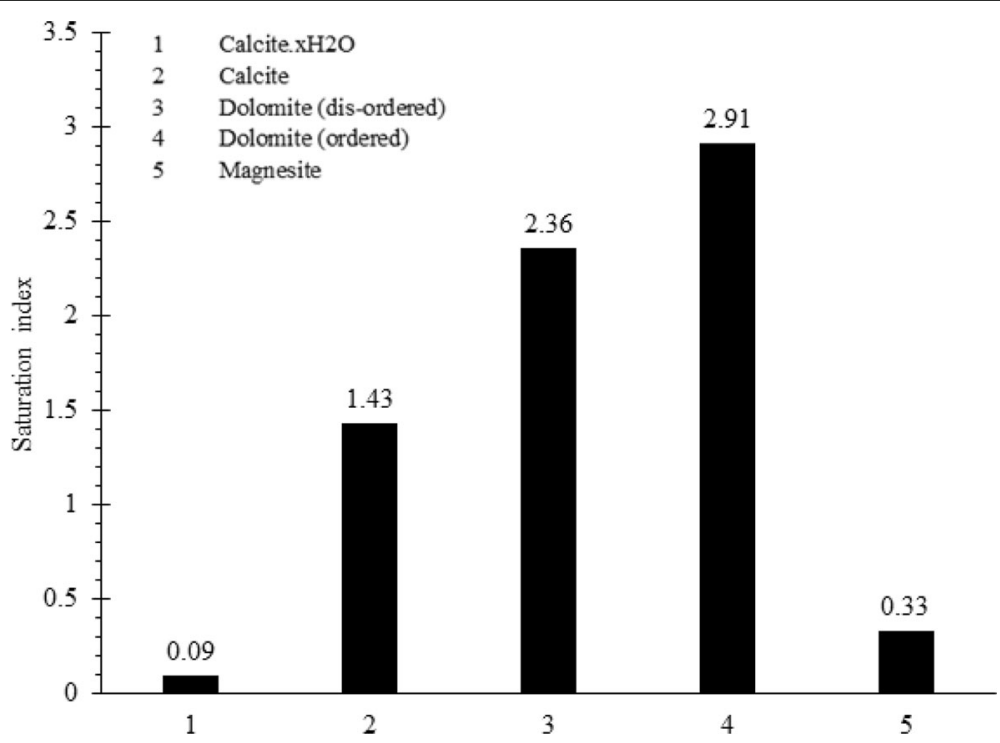

Fig. 9 Saturation index of carbonate minerals formed in alkaline lake water sample 
deficiency of divalent cations in the lakes is attributed to their precipitation as carbonate minerals (Fig. 9) and ion-exchange reactions between monovalent ions of sediments and divalent cations in lake water (discussed in section 4.4). Precipitation and ion-exchange reactions increases the relative proportion of $\mathrm{Na}^{+}$to $\mathrm{Ca}^{2+}$ ions (median value of ratio $=1.61$ ) in the lake samples.

The $\mathrm{Ca}^{2+} / \mathrm{Mg}^{2+}$ molar ratios of the lake water samples ranged between 0.52 and 0.88 for $37 \%$ of the samples and exceeded unity (1.07 to 1.62$)$ for the remaining samples. Dissolution of anthropogenic gypsum [11] apparently contributed to the presence of excess $\mathrm{Ca}^{2+}$ ions causing the $\mathrm{Ca}^{2+} / \mathrm{Mg}^{2+}$ molar ratio to exceed unity in many lake samples. In addition, release of $\mathrm{SO}_{4}{ }^{2-}$ ions from gypsum dissolution is possibly responsible for the higher anion concentration (median value $=40 \mathrm{mg} \mathrm{L}^{-1}$ ) in the lakes than in the MWW samples (median value $=20 \mathrm{mg} \mathrm{L}^{-1}$ ). About 26,192 gypsum idols were immersed in different lakes of Bengaluru city in 2017 and 2018 [54].

Besides anthropogenic gypsum dissolution, $\mathrm{SO}_{4}{ }^{2-}$ ion concentration in the lakes is contributed by rainwater (3.9 $\mathrm{mg} \mathrm{L}^{-1}$, [55]) and MWW contamination. Assuming that the (i) $\mathrm{SO}_{4}{ }^{2-}$ ions in lake water are in equilibrium with ions trapped in the pore solution of the sediments and (ii) dilution effects is balanced by enrichment of the anion concentration from evaporation, it follows that:

$$
\begin{aligned}
& \mathrm{SO}_{4} \text { concentration from gyspum dissolution } \\
& =\left(\text { Median } \mathrm{SO}_{4} \text { concentration in lakes }\right) \\
& -\left(\text { Median } \mathrm{SO}_{4} \text { concentration in } \mathrm{MWW}\right. \\
& \left.+ \text { Mean } \mathrm{SO}_{4} \text { concentration in rainwater }\right)=40-(20+3.9)=16.1 \mathrm{mg} \mathrm{L}^{-1}
\end{aligned}
$$

Mass balance calculations indicate that $\mathrm{SO}_{4}{ }^{2-}$ ions produced from gypsum dissolution $\left(16.1 \mathrm{mg} \mathrm{L}^{-1}\right)$ would release $6.7 \mathrm{mg} \mathrm{L}^{-1}$ of $\mathrm{Ca}^{2+}$ ions to the lakes. The median
$\mathrm{Ca}^{2+}$ ion concentration $\left(24.5 \mathrm{mg} \mathrm{L}^{-1}\right)$ in the lake samples (Table 2) indicates that gypsum dissolution contributed to $27 \%$ of available $\mathrm{Ca}^{2+}$ ion concentration in the lake samples; the reminder (73\%) is attributed to contributions from MWW contamination and lithology of catchments.

\section{Sink (sediment)-source (lake water) interactions}

The PU, UL and NG lake sediments are characterized by organic contents 10.4, 16.2, and 5.8\% and gravimetric water contents of 366,722 , and $235 \%$ respectively (Table 6). The results indicate that sediments with higher organic matter $(\mathrm{OM})$ are characterized with larger gravimetric water content. The large water holding capacity of humus [45] is apparently responsible for the notable water contents of the sediments ( 235 to $722 \%$ ). The large water contents allow dissolution of solutes in the pore solutions of the sediments (TDS ranges from 165 to $301 \mathrm{mg} \mathrm{L}^{-1}$ ). The pore solutes (determined from water leaching test) of PU and UL sediments (Table 6) are dominated by anions $\left(\mathrm{Z}^{-}\right.$total $=122$ to $129 \mathrm{mg} \mathrm{L}^{-1}$ ) with major contributions from $\mathrm{HCO}_{3}{ }^{-}$and $\mathrm{SO}_{4}{ }^{2}$ - ions. The $\mathrm{Ca}^{2+}$ and $\mathrm{Mg}^{2+}$ ions mainly contribute to the pore solute cations and the $\mathrm{Z}^{+}$total values range from 81 to 88 $\mathrm{mg} \mathrm{L}^{-1}$. The pore solution of Nagawara sediment has slightly higher concentration of cations $\left(\mathrm{Z}^{+}{ }_{\text {total }}=3.76\right.$ meq $\left.\mathrm{L}^{-1}\right)$ than anions $\left(0.79 \mathrm{meq} \mathrm{L}^{-1}\right)$. The sum of anions is less than the sum of cations owing to bicarbonate consumption during algal photosynthesis. The pore solution salinity (TDS) of the sediments (Table 6) is lower than of lake water (Table 2). The resulting chemical concentration gradient favors solute diffusion from lake water into the pore solutions of sediments.

Besides pore solutes, the adsorbed cations of the sediments would also participate in sink-source interactions.

\begin{tabular}{|c|c|c|c|c|c|c|c|c|c|c|}
\hline \multirow{2}{*}{$\begin{array}{l}\text { Lake } \\
\text { sediment }\end{array}$} & \multirow{2}{*}{$\begin{array}{l}\text { Gravimetric } \\
\text { water } \\
\text { content (\%) }\end{array}$} & \multirow{2}{*}{$\begin{array}{l}\text { Organic } \\
\text { matter } \\
(\%)\end{array}$} & \multirow{2}{*}{$\begin{array}{l}\text { TDS } \\
\text { (from } \\
\text { EC } \\
\text { test; } \\
\text { mg } \\
L^{-1} \text { ) }\end{array}$} & \multicolumn{7}{|c|}{ Ion composition of water leachate $\left(\mathrm{mg} \mathrm{L}^{-1}\right)$} \\
\hline & & & & $\mathrm{Ca}^{2+}$ & $\mathrm{Mg}^{2+}$ & $\mathrm{Na}^{+}$ & $\mathrm{K}^{+}$ & $\mathrm{HCO}_{3}^{-}$ & $\mathrm{SO}_{4}^{2-}$ & $\mathrm{Cl}^{-}$ \\
\hline Puttenahalli & 366 & 10.4 & 286 & 47.9 & 33.0 & 4.2 & 2.4 & 73.2 & 52.5 & 4.3 \\
\hline Ulsoor & 722 & 16.2 & 301 & 46.3 & 30.1 & 2.8 & 1.9 & 87.5 & 34.3 & 0 \\
\hline \multirow[t]{3}{*}{ Nagawara } & 235 & 5.8 & 165 & 4.1 & 37.2 & 7.2 & 5.4 & 11.2 & 29.1 & 0 \\
\hline & & & & \multicolumn{7}{|c|}{ Exchangeable cations (ammonium acetate extract; meq $100 \mathrm{~g}^{-1}$ ) } \\
\hline & & & & $\mathrm{Ca}^{2+}$ & $\mathrm{Mg}^{2+}$ & $\mathrm{Na}^{+}$ & $\mathrm{K}^{+}$ & & & \\
\hline Puttenahalli & & & & 18.8 & 36 & 0.52 & 0.25 & & & \\
\hline Ulsoor & & & & 76.2 & 51.2 & 0.7 & 0.38 & & & \\
\hline Nagawara & & & & 5.1 & 100.3 & 0.46 & 0.66 & & & \\
\hline
\end{tabular}
The adsorption sites of the sediments are contributed by the exchange sites of mineral fraction and the $\mathrm{pH}$

Table 6 Characteristics of lake sediments 
dependent sites of the humus fraction of organic matter $[45,56]$. The ammonium acetate extracts of the sediments (Table 6) dominated in $\mathrm{Ca}^{2+}$ and $\mathrm{Mg}^{2+}$ ions $\left(\mathrm{Z}_{(\mathrm{Ca}+\mathrm{Mg}) \text { exchangeable }}=55\right.$ to $\left.127 \mathrm{meq} 100 \mathrm{~g}^{-1}\right)$. The cation exchange capacity (CEC) of Bengaluru soils range from 1.9 to $22 \mathrm{meq} 100 \mathrm{~g}^{-1}$ with median value of 12.8 meq $100 \mathrm{~g}^{-1}$ [29]. The sum of exchangeable cations $\left(\mathrm{Z}^{+}\right.$exchangeable $)$of the lake sediments range from 55.6 to 128.5 meq $100 \mathrm{~g}^{-1}$ which is > CEC of Bengaluru soils. The results suggest that in addition to the inorganic mineral fraction, the organic coatings on the lake sediments significantly contribute to their exchangeable cation content. The carboxyl, phenolic-OH, amino and carbonyl groups of the humic and non-humic substances in lake sediments develop $\mathrm{pH}$ dependent charges and significantly contribute to the cation adsorption sites $[45,56]$. Ion-exchange reactions between adsorbed $\mathrm{Na}^{+}$ and $\mathrm{K}^{+}$ions of lake sediments with $\mathrm{Ca}^{2+}$ and $\mathrm{Mg}^{2+}$ ions of lake water possibly enriched the adsorbed divalent cation content of sediment particles as [57]:

$$
2 \mathrm{NaX}+\mathrm{Ca}^{2+} \rightarrow 2 \mathrm{Na}^{+}+\mathrm{CaX}_{2}
$$

The ion-exchange reaction (Eq. 6) would also contribute to depletion of divalent cation concentration in the lakes.

\section{Implications of MWW contamination on lake water classification}

Table 7 provides an excerpt of water quality parameters used to classify water resources [58] for water supply with conventional treatment (Class IIA), or for recreational use with body contact (Class IIB). In the present study, Malaysian water quality index [58] is chosen over Indian surface water quality standards to enable inclusion of COD parameter (indicator of organic contamination) for the lake classification. The Indian surface water quality standards do not specify tolerance limits for COD [59]. The median values of the Bengaluru lakes indicate that owing to high COD $\left(>25 \mathrm{mg} \mathrm{L}^{-1}\right)$, high $\mathrm{pH}$ $(>8.7)$ and DO (>5-7 $\left.\mathrm{mg} \mathrm{L}^{-1}\right)$, the lakes do not categorize as class IIA or IIB. The presence of nonpermissible $\mathrm{Al}^{3+}$ ion concentrations $\left(>0.2 \mathrm{mg} \mathrm{L}^{-1}\right)$ renders the lake water toxic. Presence of sewage in the MWW can be expected to impart fecal coliform counts $>400 \mathrm{CFU} 100 \mathrm{~mL}^{-1}$ in the lakes. Besides, alterations in major ion chemistry, organic and microbial contamination, biochemical reactions associated with photosynthesis activity of algae and release of toxic metals from mineral dissolution are the consequences of contamination of Bengaluru lakes. Stopping the flow of partially treated or untreated sewage in the lakes is essential to restore their physical, chemical and biological characteristics.

\section{Conclusions}

Anthropogenic activity impacted the major ion composition of Bengaluru lakes and aquifers. The concentrations of most major ions in Bengaluru city groundwater are higher than the corresponding MWW values. Occurrence of zones of poor drainage, flat slopes and shallow groundwater makes the Bengaluru aquifers vulnerable to anthropogenic pollution. The ionic ratio plot of Bengaluru lakes implies that the major ion composition of the lake samples is influenced by anthropogenic activities than by the lithology of the drainage catchments indicating that outfall of sewage treatment plant and outlets of stormwater drains have contaminated the Bengaluru lakes.

Enrichment of $\mathrm{Mg}^{2+}, \mathrm{Na}^{+}$and $\mathrm{Cl}^{-}$ions from anthropogenic contamination changed the hydrochemical-facies of the lake water. The lake samples classify as mixed Ca$\mathrm{Na}-\mathrm{HCO}_{3}$ and mixed $\mathrm{Ca}-\mathrm{Mg}-\mathrm{Cl}$ types, while, nonpolluted IISc groundwater samples classify as $\mathrm{Ca}-\mathrm{HCO}_{3}$ type of water. Rock-weathering influences the chemical composition of non-polluted IISc groundwater samples, while, evaporation tends to dominate the chemical characteristics of lake water. Interactions of $\mathrm{NaCl}$ particles with atmosphere during evaporation altered the $\mathrm{Na} / \mathrm{Cl}$ balance of the lake samples. The alkaline $\mathrm{pH}$ due to photosynthetic metabolism of algae facilitated precipitation of carbonate minerals and a deficit of $\mathrm{Ca}$ and $\mathrm{Mg}$

Table 7 Classification of lakes based on select parameters [58]

\begin{tabular}{llll}
\hline Parameter & $\begin{array}{l}\text { Class II A: Water supply with conventional } \\
\text { treatment }\end{array}$ & $\begin{array}{l}\text { Class IIB: Recreational use with body } \\
\text { contact }\end{array}$ & $\begin{array}{l}\text { Median concentration of } \\
\text { Bengaluru Lakes }\end{array}$ \\
\hline $\begin{array}{l}\text { Ammoniacal Nitrogen }(\mathrm{mg} \\
\left.\mathrm{L}^{-1}\right)\end{array}$ & 0.3 & 0.3 & 0 \\
$\mathrm{COD}\left(\mathrm{mg} \mathrm{L}^{-1}\right)$ & 25 & 25 & 41 \\
$\mathrm{DO}\left(\mathrm{mg} \mathrm{L}^{-1}\right)$ & $5-7$ & $5-7$ & 12.5 \\
$\mathrm{pH}$ & 6.5 to 9.0 & $6.5-9.0$ & 9.1 \\
$\begin{array}{l}\text { Electrical Conductivity }(\mu \mathrm{S} \\
\left.\mathrm{Cm}^{-1}\right)\end{array}$ & 1000 & - & 610 \\
$\begin{array}{l}\text { Faecal Coliform (CFU } 100 \\
\mathrm{~mL}^{-1} \text { ) }\end{array}$ & 100 & 400 & Not tested \\
\hline
\end{tabular}


ions in the lakes. Ion-exchange reactions between adsorbed cations of lake sediments and lake water solutes also contributed to deficit of divalent cations in the lakes. Dissolution of anthropogenic gypsum contributed to $27 \%$ of available $\mathrm{Ca}^{2+}$ ion concentration in the lake samples and the reminder (73\%) is contributed by MWW contamination and lithology of drainage catchments. Besides alterations in major ion chemistry, organic contamination, biochemical reactions associated with photosynthesis activity of algae and release of toxic $\mathrm{Al}^{3+}$ ions from chemical weathering of lake sediments are the consequences of lake contamination.

\section{Acknowledgments}

The authors thank Karnataka Tank Conservation and Development Authority, Government of Karnataka, Bruhat Bengaluru Mahanagara Palike (Bengaluru Municipal Corporation) for giving us permission to obtain samples from the lakes. The authors thank Puttenahalli Neighbourhood Lake Improvement Trust for facilitating sampling from Puttenahalli lake.

\section{Authors' contributions}

Sudhakar Rao (SR), Priscilla A (PA), Nitish VM (NVM), Lydia A (LA) designed the field sampling and field/laboratory measurements. PA, NVM and LA performed the field sampling and experiments. SR, PA, NVM and LA were involved in analysis and interpretation of the results. SR wrote the manuscript in consultation with PA, NVM and LA. The author(s) read and approved the final manuscript.

\section{Funding}

The authors acknowledge Earthwatch Institute India Trust, for funding the project on "Lakes of Bengaluru as drivers of an enriched blue-green cityscapes."

\section{Availability of data and materials}

All data used in the study appear in the submitted article.

\section{Competing interests}

The authors declare that they have no competing interests.

\section{Author details}

${ }^{1}$ Department of Civil Engineering, Indian Institute of Science, Bengaluru 560012 , India. ${ }^{2}$ Centre for Sustainable Technologies, Indian Institute of Science, Bengaluru 560012, India.

Received: 4 July 2019 Accepted: 14 April 2020

Published online: 11 May 2020

\section{References}

1. Norton SA, Brakke DF, Kahl JS, Haines TA. Major influences on lake water chemistry in Maine. Maine Geol Surv. 1989;5:109-24.

2. Roy S, Gaillardet J, Allegre CJ. Geochemistry of dissolved and suspended loads of the seine river, France: anthropogenic impact, carbonate and silicate weathering. Geochim Cosmochim Ac. 1999;63:1277-92.

3. Kumarasamy P, James RA, Dahms HU, Byeon CW, Ramesh R. Multivariate water quality assessment from the Tamiraparani river basin, Southern India. Environ Earth Sci. 2014;71:2441-51.

4. Jiang LG, Yao ZJ, Liu ZF, Wang R, Wu SS. Hydrochemistry and its controlling factors of rivers in the source region of the Yangtze River on the Tibetan plateau. J Geochem Explor. 2015;155:76-83.

5. Hem JD. Study and interpretation of the chemical characteristics of natural water. 3rd ed. Alexandria: US Geological Survey; 1985.

6. Meybeck M, Helmer R. The quality of rivers: from pristine stage to global pollution. Glob Planet Chang. 1989;75:283-309.

7. Han GL, Liu CQ. Water geochemistry controlled by carbonate dissolution: a study of the river waters draining karst-dominated terrain, Guizhou Province, China. Chem Geol. 2004;204:1-21.
8. Barzegar R, Moghaddam AA, Tziritis E. Assessing the hydrogeochemistry and water quality of the Aji-Chay River, northwest of Iran. Environ Earth Sci. 2016;75:1486.

9. Jalali M. Geochemistry characterization of groundwater in an agricultural area of Razan, Hamadan, Iran. Environ Geol. 2009;56:1479-88.

10. Jeelani G, Shah AQ. Geochemical characteristics of water and sediment from the dal Lake, Kashmir Himalaya: constraints on weathering and anthropogenic activity. Environ Geol. 2006;50:12-23.

11. Reddy MV, Babu KS, Balaram V, Satyanarayanan M. Assessment of the effects of municipal sewage, immersed idols and boating on the heavy metal and other elemental pollution of surface water of the eutrophic Hussainsagar Lake (Hyderabad, India). Environ Monit Assess. 2012;184:1991-2000.

12. Metcalf \& Eddy Inc. Wastewater engineering: treatment and resource recovery. 5th ed. New York: McGraw-Hill; 2014

13. Schouw NL, Danteravanich S, Mosbaek H, Tjell JC. Composition of human excreta - a case study from southern Thailand. Sci Total Environ. 2002;286: 155-66.

14. Nishimuta M, Inoue N, Kodama N, Morikuni E, Yoshioka YH, Matsuzaki N, et al. Moisture and mineral content of human feces - high fecal moisture is associated with increased sodium and decreased potassium content. J Nutr Sci Vitaminol. 2006;52:121-6.

15. Palmquist $\mathrm{H}$, Hanaeus J. Hazardous substances in separately collected greyand Blackwater from ordinary Swedish households. Sci Total Environ. 2005; 348:151-63.

16. Rose $\mathrm{S}$. The effects of urbanization on the hydrochemistry of base flow within the Chattahoochee River basin (Georgia, USA). J Hydrol. 2007;341:4254.

17. Bhatt MP, McDowell WH. Evolution of chemistry along the Bagmati drainage network in Kathmandu valley. Water Air Soil Poll. 2007;185:165-76.

18. Rao SM, Arkenadan L, Mogili NV, Atishaya SK, Anthony P. Bioremediation of pit toilet sewage. J Environ Eng Sci. 2017;12:26-33.

19. Rao SM, Arkenadan L, Mogili NV. Performance of modified twin pit toilet in Mulbagal town, Karnataka, India. J Water Sanit Hyg De. 2018;8:578-84.

20. Wurts WA, Durborow RM. Interactions of $\mathrm{pH}$, carbon dioxide, alkalinity and hardness in fish ponds. Stoneville: Southern Regional Aquaculture Center; 1992.

21. Lopez-Archilla Al, Moreira D, Lopez-Garcia P, Guerrero C. Phytoplankton diversity and cyanobacterial dominance in a hypereutrophic shallow lake with biologically produced alkaline pH. Extremophiles. 2004;8:109-15.

22. Scholz M. Wetland systems to control urban runoff. 1st ed. Amsterdam: Elsevier; 2006

23. Yu T, Xu QJ, He CD, Cong HB, Dai D, Wu FC, et al. Long-term trends in acid neutralizing capacity under increasing acidic deposition: a special example of eutrophic Taihu Lake, China. Environ Sci Technol. 2016;50:12660-8.

24. Hartley AM, House WA, Callow ME, Leadbeater BSC. The role of a green alga in the precipitation of calcite and the coprecipitation of phosphate in freshwater. Int Rev Ges Hydrobio. 1995:80:385-401.

25. Deutsch WJ, Siegel R. Groundwater geochemistry: fundamentals and applications to contamination. Boca Raton: CRC Press; 1997.

26. Jumbe AS, Nandini K, Tandon S, Sunitha N. Bangalore lakes-issues and perspective on pollution, restoration and management. In: 12th World Lake Conference. Jaipur; 2007 Oct 28-Nov 2.

27. Shiva Kumar KV. Water quality monitoring of lakes in Bangalore. In: 12th World Lake Conference. Jaipur; 2007 Oct 28-Nov 2.

28. Ramachandra TV, Sincy V, Asulabha KS, Sudarshan PB, Rahaman MF. Recurring fish mortality episodes in Bangalore Lakes - sign of irresponsible and fragmented governance. Bengaluru: Indian Institute of Science; 2016.

29. Rao SM, Venkatesh KH. Residual soils of India. In: Huat BK, Toll DG, Prasad A, editors. Handbook of tropical residual soil engineering. Boca Raton: CRC Press; 2012. p. 463-90.

30. DMG. Groundwater Hydrology and Groundwater Quality in and around Bangalore City. Bengaluru: Department of Mines and Geology; 2011

31. Ramachandra TV, Vinay S, Asulabha KS, Sincy V, Sudarshan B, Durga MM, et al. Rejuvenation blueprint for lakes in Vrishabhavathi Valley. Bengaluru: Indian Institute of Science; 2017.

32. EMPRI. KLCDA-BDA lake list. Bengaluru: Environmental Management and Policy Research Institute; 2016.

33. Ramachandra TV, Asulabha KS, Sincy V, Vinay S, Sudarshan PB, Bharath HA Sankey Lake: waiting for an immediate sensible action. Bengaluru: Indian Institute of Science; 2015. 
34. PNLIT. Information on Puttenahalli Lake. Bengaluru: Puttenahalli Neighbourhood Lake Improvement Trust; 2010.

35. TOI. 150 fish die in Puttenahalli lake; residents suggest aerators. Mumbai: The Times of India; 2018.

36. Gulgundi MS, Shetty A. Groundwater quality assessment of urban Bengaluru using multivariate statistical techniques. Appl Water Sci. 2018;8:43.

37. Rao SM. Report on water quality Management for Indian institute of science (IISC) campus. Bengaluru: Indian Institute of Science; 2009.

38. APHA. Standard methods for the examination of water and wastewater. 20th ed. Washington, DC: American Public Health Association; 1998.

39. Fetter CW. Applied hydrogeology. 2nd ed. New Delhi: CBS Publishers and Distributors; 2007.

40. Parsons TR, Strickland JDH. Discussion of spectrophotometric determination of marine-plant pigments, with revised equations for ascertaining chlorophylls and carotenoids. J Mar Res. 1963:21:155-63.

41. Carlson RE. A trophic state index for lakes. Limnol Oceanogr. 1977;22:361-9.

42. ASTM. Standard practice for shake extraction of solid waste with water (D3987-12). West Conshohocken: American Society for Testing and Materials International; 2012.

43. BIS. Methods of Test for Soils-Determination of Cation Exchange Capacity (IS 2720-24). New Delhi: Bureau of Indian Standards; 1976.

44. BIS. Drinking Water - Specification (IS 10500). New Delhi: Bureau of Indian Standards; 2012

45. Brady NC, Weil RR. The nature and properties of soils. 14th ed. Upper Saddle River: Pearson; 2008.

46. Wetzel RG. Limnology: lake and river ecosystems. 3rd ed. San Diego: Academic Press; 2001.

47. Muller R, Stadelmann P. Fish habitat requirements as the basis for rehabilitation of eutrophic lakes by oxygenation. Fisheries Manag Ecol. 2004; 11:251-60.

48. Watson SB, Miller C, Arhonditsis G, Boyer GL, Carmichael W, Charlton MN, et al. The re-eutrophication of Lake Erie: harmful algal blooms and hypoxia. Harmful Algae. 2016;56:44-66.

49. Berner EK, Berner RA. The global water cycle: geochemistry and environment. Englewood Cliffs: Prentice Hall; 1987.

50. Ramiah BK, Rao SK. Soil distribution and engineering problems in Bangalore area. Bengaluru: Bangalore University; 1969.

51. Barzegar R, Moghaddam AA, Nazemi AH, Adamowski J. Evidence for the occurrence of hydrogeochemical processes in the groundwater of Khoy plain, northwestern Iran, using ionic ratios and geochemical modeling. Environ Earth Sci. 2018;77:597.

52. Mæller $\mathrm{D}$. The $\mathrm{Na} / \mathrm{cl}$ ratio in rainwater and the seasalt chloride cycle. Tellus B. 1990;42:254-62.

53. Subramani T, Rajmohan N, Elango L. Groundwater geochemistry and identification of hydrogeochemical processes in a hard rock region, Southern India. Environ Monit Assess. 2010;162:123-37.

54. TNIE. Despite ban over 12,000 plaster of Paris idols immersed in south Bengaluru. Chennai: The New Indian Express; 2018

55. Pasha GM, Shivashankara GP, Tiwari S. Chemical composition and ionic variability of wet and bulk precipitation in urban environment of Karnataka state, India. Inter J Curr Res Acad Rev. 2014;2:66-84.

56. Essington ME. Soil and water chemistry: an integrative approach. 1st ed. Boca Raton: CRC Press; 2003.

57. Appelo CAJ, Postma D. Geochemistry, groundwater and pollution. 2nd ed. Leiden: A.A. Balkema Publishers; 2005.

58. DOE. Malaysian Environmental Quality Report 2006. Putrajaya: Department of Environment; 2006

59. BIS. Tolerance Limits for Inland Surface Waters Subject to Pollution (IS 2296). New Delhi: Bureau of Indian Standards; 1982.

\section{Publisher's Note}

Springer Nature remains neutral with regard to jurisdictional claims in published maps and institutional affiliations.

Ready to submit your research? Choose BMC and benefit from:

- fast, convenient online submission

- thorough peer review by experienced researchers in your field

- rapid publication on acceptance

- support for research data, including large and complex data types

- gold Open Access which fosters wider collaboration and increased citations

- maximum visibility for your research: over $100 \mathrm{M}$ website views per year

At $\mathrm{BMC}$, research is always in progress.

Learn more biomedcentral.com/submissions 